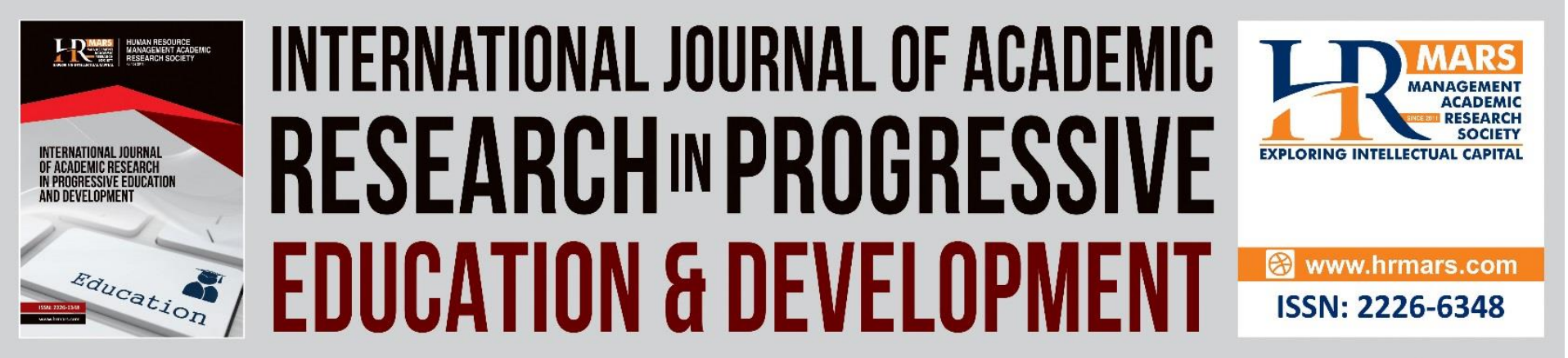

\title{
Classroom Assessment Practices in Malaysian Primary Schools: A Meta-Analysis
}

Rodhiana Rosli, Siti Eshah Mokhsein, Zahari Suppian

To Link this Article: http://dx.doi.org/10.6007/IJARPED/v11-i1/11516

DOI:10.6007/IJARPED/v11-i1/11516

Received: 09 November 2021, Revised: 02 December 2021, Accepted: 27 December 2021

Published Online: 10 January 2022

In-Text Citation: (Rosli et al., 2022)

To Cite this Article: Rosli, R., Mokhsein, S. E., \& Suppian, Z. (2022). Classroom Assessment Practices in Malaysian Primary Schools: A Meta-Analysis. International Journal of Academic Research in Progressive Education and Development, 11(1), 97-111.

Copyright: (C) 2022 The Author(s)

Published by Human Resource Management Academic Research Society (www.hrmars.com)

This article is published under the Creative Commons Attribution (CC BY 4.0) license. Anyone may reproduce, distribute, translate and create derivative works of this article (for both commercial and non-commercial purposes), subject to full attribution to the original publication and authors. The full terms of this license may be seen

at: http://creativecommons.org/licences/by/4.0/legalcode

Vol. 11(1) 2022, Pg. 97 - 111

Full Terms \& Conditions of access and use can be found at http://hrmars.com/index.php/pages/detail/publication-ethics 


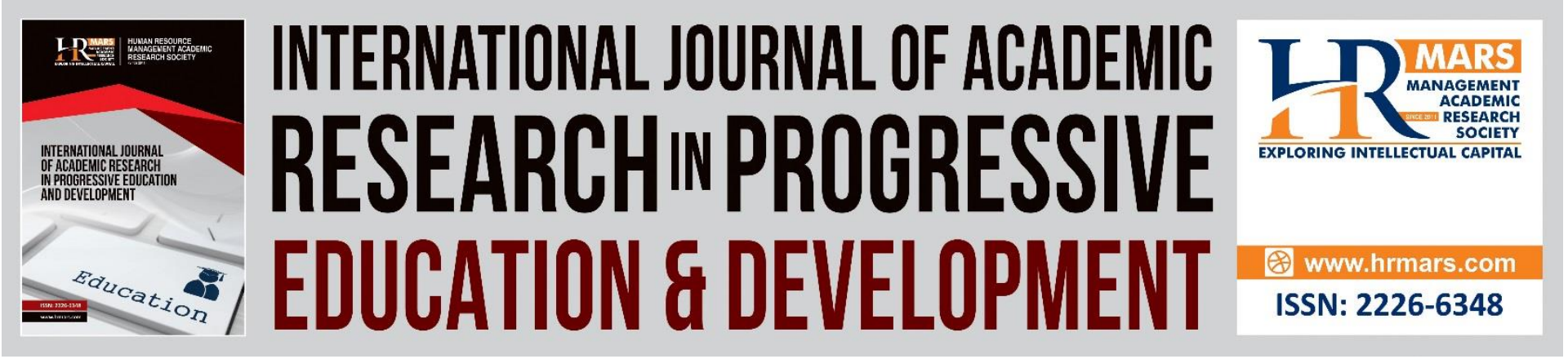

\title{
Classroom Assessment Practices in Malaysian Primary Schools: A Meta-Analysis
}

\author{
Rodhiana Rosli, Siti Eshah Mokhsein, Zahari Suppian \\ Department of Educational Studies Faculty of Human Development, Universiti Pendidikan \\ Sultan Idris, Tanjung Malim, Perak, Malaysia. \\ Email: rodhianarosli29@gmail.com, eshah@fpm.upsi.edu.my
}

\begin{abstract}
One of the assessment processes used by teachers to help students improve is classroom assessment. Teachers will determine the extent to which students comprehend the topic of learning through classroom assessment. However, issuing implementation instructions in a short period might lead to a range of problems. As a result, the challenges, methodology, and conclusions of prior research on classroom assessment practise in Malaysian primary schools are examined in this paper. This study uses a meta-analysis design and a secondary study form to identify, explore, and interpret all relevant studies related to a topic domain. The review will only include studies conducted between 2020 and 2021 due to a recent change in assessment practices in Malaysian primary schools. A single database, Google Scholar, was used to find relevant literature and keywords were used to find the article. The three criteria used to select articles for analysis were researched on classroom assessment, data collection, and research completed within the last two years. Finally, 12 articles were chosen for metaanalysis based on a review of the literature. There are five qualitative studies and seven quantitative studies included. The findings revealed inconsistencies in Malaysian primary school teachers' reports about their readiness to understand classroom assessment. Previous research on Malaysian classroom assessment practices, on the other hand, used credible methodologies because each study examined a different aspect of the subject. In the future, researchers should concentrate their efforts on developing an instrument that meets validity and reliability criteria, resulting in more reliable data.
\end{abstract}

Keywords: Classroom Assessment, Meta-Analysis, Primary School, Malaysia

\section{Introduction}

Classroom assessment is a type of continuous assessment used by teachers in teaching and learning. Classroom assessment enables teachers to gather, understand, and utilize assessment data to make decisions about their students' understanding of various subjects (Black \& William, 2018; Ghazali et al., 2018; McMillan, 2018; Rahman, 2018; Pilok et al., 2019; Omar, 2019). Shepard (2019) defines classroom assessment as both formative and summative assessment. Formative assessment is a technique used to improve the instructional process and help students improve their performance. Summative assessment, on the other hand, is used to grade or validate student achievement. 
DEVELOPMENT

Vol. 11, No. 1, 2022, E-ISSN: 2226-6348 @ 2022 HRMARS

Classroom assessment is not a new practice in Malaysia. Since 2011, classroom assessment has been used as part of School-Based Assessment. Classroom assessment was previously known as School Assessment before being renamed Classroom Assessment in 2016. The instruction on the implementation of classroom assessment for level 1 primary school students, on the other hand, is a new mandate that must be implemented starting in 2019. These changes caught the attention of previous researchers, who attempted to understand the instructions' implications. As a result, this meta-analysis study will look at a large body of previous research on classroom assessment practises in Malaysian primary schools.

This research will be conducted to answer the following research questions:

i. What issues have been chosen for Malaysian classroom assessment research?

ii. What were the research methods used to conduct classroom assessment research in Malaysia?

iii. What are the most critical findings from the Malaysian classroom assessment study?

As a consequence, the study's objectives are to determine:

i. the issues have been chosen for Malaysian classroom assessment research,

ii. the research methodologies used to conduct Malaysian classroom assessment research, and

iii. the most critical findings from the Malaysian classroom assessment study.

\section{Literature Review}

The researchers identified twelve classroom assessment studies conducted previously by Malaysian researchers. To begin, Dorin and Yasin (2019) researched to determine the level of teacher readiness for classroom assessment implementation. Teachers' readiness is assessed based on their knowledge, skills, and attitudes. A more objective classroom assessment has been introduced to determine students' level of mastery in each subject. This level of mastery is defined in the Curriculum and Assessment Standards Document by the Performance Standards for all topics in the Primary School Standard Curriculum. Even though classroom assessment has been in use since 2016, not all teachers can use and integrate it in their classrooms. This study's data was gathered through a survey method, with a questionnaire as an instrument. 170 primary school teachers from the Padawan district were chosen as respondents. The study's data were analysed descriptively. According to the findings of this study, teachers' readiness for classroom assessment implementation ranges between moderate and high.

Isa et al (2020) conducted a study on teacher autonomy in classroom assessment implementation. This study attempted to determine the impact of assessment reforms on teacher autonomy in terms of differences based on demographics and whether mid-year and end-of-year examinations are still administered in schools as part of classroom assessment by evaluating the level of teacher autonomy. In the quantitative approach with survey method, a questionnaire instrument was used on 58 primary school teachers teaching level 1 students using a simple randomly selected sample. The findings of this study show that teacher autonomy is high, and aspects of education differ significantly from teacher autonomy; additionally, more than half of the respondents still use examinations as part of classroom assessment. Finally, teacher autonomy issues and challenges are discussed, along with 
recommendations on the roles of school administrators, District Education Office, State Education Department, and Malaysia Education Ministry in teacher empowerment, teachers' awareness of increased accountability in line with increased autonomy, and ongoing impact studies.

Khory et al (2021) study can also be used as a reference. They investigated the approach used by Arabic teachers in conducting classroom assessments based on their students' learning needs in their study. The study used two data collection techniques, such as in-depth interviews and document analysis. Three teachers have been chosen to participate in the study. This study examined the teaching and teacher assessment methods in depth before they were implemented. As a result, teachers must have a well-thought-out plan before beginning the teaching and learning process in the classroom. As a result, teachers should create a Students Proficiency Report that demonstrates students' actual achievement and can be used for various purposes.

Arumugham conducted a study to learn how Malaysian primary school teachers implement classroom assessment (2020). The two main areas studied are integrating curriculum, teaching, assessment, and implementing classroom assessment. Because this study aims to learn more about teachers' strategies for implementing classroom assessment, the researcher used a qualitative approach. Ten teachers were chosen as study participants to collect data on classroom assessment implementation. The researcher conducted interviews and observations during the data collection phase. Based on the information gathered, the findings were organized into themes. Three themes have been proposed to demonstrate how teachers integrate curriculum, teaching, and assessment and implement classroom assessment. However, researchers have discovered that teachers still require ongoing supervision and guidance to ensure that all teachers understand and correctly implement classroom assessment. This study also reveals that there are some gaps that policymakers must fill to meet the implementation goals.

Furthermore, Lee et al (2020) incorporated three components from the "Cycle Impact Model" into their research. The purpose of this study was to investigate an instructional coach's experience working with a primary school teacher as part of an Instructional Guidance Implementation of Classroom Assessment procedure. Discussions with the instructional coach and teacher have taken place. Researchers also conduct classroom observations and record reviews. According to the findings, the teacher better understood 'Assessment as Learning in the classroom. By considering students with varying levels of achievement in the classroom, a collaborative approach can also assist the teacher in considering various teaching strategies to achieve higher levels of student mastery according to performance standards as mentioned in the Curriculum and Assessment Standards Document. On the other hand, instructional coaches should consider sharing more information about various teaching methods, teaching modelling, and developing appropriate checklists to assist teachers in implementing various teaching strategies. Classroom assessment's success depends on ongoing dialogue and instructional guidance between the instructional coach and the teacher.

In addition, Lius and Mahamod (2021) conducted a study to assess the stress levels of Malay language teachers during the implementation of classroom assessment at Sekolah Jenis 
Kebangsaan Cina (SJKC). A questionnaire based on workload, discipline, interpersonal connections, Malay language instruction, and professional recognition assessed teachers' stress levels during classroom assessment implementation. Furthermore, 128 Malay language teachers from 13 SJKCs were examined using a quantitative methodology. According to the findings, changes in assessment practises, such as the implementation of classroom assessment in primary schools, cause teachers to feel anxious and stressed. Furthermore, the findings of the study suggest that teacher stress affects classroom assessment strategies.

Following that, Salleh et al (2019) looked into teachers' understanding of the three classroom assessment approaches assessment for learning, assessment as learning, and assessment of learning. A cross-sectional study was conducted in which 500 teachers from Kedah were chosen to complete an online questionnaire. The researchers used the Approaches to Classroom Assessment Inventory (ACAl; DeLuca et al., 2016) as the study's instrument. The data were descriptively analyzed using numbers and percentages. According to the findings, most teachers choose a consistent method based on the concept of classroom assessment. 32.5 percent to 68.3 percent of respondents used the assessment for learning, while 24.8 percent to 46.9 percent used it as a learning approach. Finally, this study shows that teachers are already familiar with the implementation of classroom assessment.

In classroom assessment, Khamis and Selamat (2019) conducted a feedback study. In that study, researchers look into how primary Cluster School of Excellence teachers in Malacca use feedback in classroom assessment. Furthermore, the researchers focused on understanding the concept of classroom assessment and reviewing the impact of providing students with feedback on their learning outcomes. Eight teachers participated in this qualitative study, including four core subject teachers from Malay, English, Science, and Mathematics, four assessment administration instructors from the Headmaster, Senior Administrative Assistant, School Assessment Coordinator, and SIC +. The results showed that the teachers' understanding of the concept and function of classroom assessment is quite explicit. Giving feedback on students' work shows that the practice is widespread, but only a tiny percentage of teachers use the feedback information.

The research of Omar (2019) then focuses on teachers' knowledge, attitude, and problemsolving abilities when implementing classroom assessments for Malay Language subjects. Classroom assessment is a comprehensive assessment that considers cognitive (intellectual), affective (emotional and spiritual), and psychomotor (physical) factors by the Primary School Standard Curriculum and the National Education Philosophy. The study included 95 Malay Language teachers from rural schools in Sarawak's Betong district. The researcher used a questionnaire as a survey instrument. The data was analysed using statistics and inferential statistics in the Statistical Package for Social Science, Version 22. (SPSS). As a result, teachers are well-prepared to implement classroom assessment, as evidenced by high mean scores in each aspect, namely teacher knowledge $(M=4.075)$, teacher skills $(M=4.037)$, and teacher attitude $(M=4.078)$. Although classroom assessment is a new concept, the findings of this study indicate that Malay Language teachers are eager to implement it.

Jusoh and Mahamod (2019) conducted additional classroom assessment research. The purpose of this study was to determine the level of knowledge, progress, and challenges encountered by Malay Language teachers in national schools when implementing Formative 
Assessment in the classroom assessment. A survey study design was used in this study, with a questionnaire serving as the research instrument. 63 Malay Language Teachers Level 1 from 42 primary schools in Betong, Sarawak were among those who responded. The findings of the study were assessed both descriptively and inferentially. Independent t-tests and Pearson correlation were used for inferential analysis. The t-test results indicated no statistically significant differences in knowledge, implementation, or teachers' use of formative assessment by gender or teacher option. Pearson correlation analysis revealed a statistically significant relationship between knowledge level and implementation, but not between variables. According to the study's findings, Malay Language teachers are fully equipped to implement the formative assessment. Additionally, the difficulties encountered by these teachers are expected to be resolved voluntarily by all parties so that formative assessment in this classroom assessment can accurately assess children's actual growth.

Yeh (2021) investigated the challenges that Visual Arts Education (VAE) teachers face when implementing classroom assessments. The purpose of this study is to determine the importance of implementation, teacher readiness, modes of assessment, and assessment strategies in VAE through interviews, observations, and document analysis. Twelve people participated in this case study: nine VAE teachers and three administrators from three different schools in the Hilir Perak district. According to the findings, most teachers are still not prepared to implement classroom assessment of VAE, which is classified as an elective and has not been emphasized. To summarise, teachers who are not prepared to implement classroom assessment, particularly those not mentioned in VAE, find it challenging to implement VAE's classroom assessment in school systematically and consistently. All parties must work together to overcome the difficulty of adapting a new and authentic assessment method for VAE.

Finally, Yuh and Kenayathulla (2020) investigated the level of classroom assessment implementation among teachers at the Sekolah Jenis Kebangsaan Cina (SJKC) in Selangor's Hulu Langat district. Furthermore, this study investigated any significant differences in classroom assessment implementation between new and experienced teachers. For this study, quantitative approaches and questionnaires were used to collect data. A total of 290 teachers were chosen at random from SJKC in the Selangor district of Hulu Langat. The study's findings were examined using descriptive and inferential statistics. According to the findings, teachers have a high level of classroom assessment implementation ( $M=3.96, \mathrm{SP}=.411)$. The $\mathrm{t}$-test, $\mathrm{t}(290)=.218, \mathrm{p}=.828$ revealed no significant difference in classroom assessment implementation between novice and experienced teachers. Furthermore, with $r(290)=.510$, $p=.000$, the study's findings revealed a significant but weak relationship between classroom assessment implementation and student performance. This study's findings will benefit school administrators, teachers, teacher education institutions, Malaysia's Ministry of Education, and future scholars.

\section{Research Methodology}

This study uses a meta-analysis design and a secondary study form to identify, explore, and interpret all relevant studies related to a topic domain (Webster \& Watson, 2002). One database, namely Google Scholar, has been selected to narrow down the scope of previous research on Classroom Assessment in Malaysia. This database was selected because it could increase the chances of finding relevant literature. Keywords such as "pentaksiran bilik 
darjah di Malaysia" (in Malay) was used to search the article. Among the criteria for selecting articles to analyse is :(i) research in the field of classroom assessment; (ii) research data collected among schools; and (iii) research is done in the last two years. Finally, a total of twelve articles were identified that met the set criteria. Table 1 shows a list of research articles related to classroom assessment in Malaysia that have been systematically analysed to answer predefined research questions.

Table 1: List of research articles related to classroom assessment in Malaysia

\begin{tabular}{|c|c|c|c|}
\hline $\begin{array}{c}\text { Researchers/ } \\
\text { Year }\end{array}$ & Journal/Proceedings/Issues & Title & Sample Size \\
\hline $\begin{array}{l}\text { Dorin \& Yasin } \\
\text { (2019). }\end{array}$ & $\begin{array}{l}\text { The International } \\
\text { Conference of Future } \\
\text { Education and Advances } \\
\text { (ICOFEA) 2019 }\end{array}$ & $\begin{array}{l}\text { Level of Readiness } \\
\text { of Teachers } \\
\text { Towards the } \\
\text { Implementation } \\
\text { of Classroom } \\
\text { Assessment }\end{array}$ & $\begin{array}{l}170 \text { primary } \\
\text { schools' } \\
\text { teachers from } \\
\text { Padawan, } \\
\text { Kuching } \\
\text { Sarawak }\end{array}$ \\
\hline $\begin{array}{l}\text { Isa et al. } \\
(2020) \text {. }\end{array}$ & $\begin{array}{l}\text { Issues and challenges in } \\
\text { education: Strategies and } \\
\text { innovation, } 2020\end{array}$ & $\begin{array}{l}\text { Transformation of } \\
\text { level } 1 \text { education: } \\
\text { Examination to } \\
\text { classroom } \\
\text { assessment (CA), } \\
\text { impact on teacher } \\
\text { autonomy }\end{array}$ & $\begin{array}{lr}58 \text { level } 1 \\
\text { primary school } \\
\text { teachers in } \\
\text { eastern } \\
\text { Malaysia. }\end{array}$ \\
\hline $\begin{array}{l}\text { Khory et al., } \\
\text { (2021). }\end{array}$ & $\begin{array}{l}\text { Journal of Educational } \\
\text { Leadership; Vol. 8, No. 2; } \\
2021\end{array}$ & $\begin{array}{l}\text { Classroom } \\
\text { Assessment } \\
\text { Management of } \\
\text { Arabic Language } \\
\text { Subjects Based on } \\
\text { Pupils' Learning } \\
\text { Needs }\end{array}$ & $\begin{array}{l}\text { Three Arabic } \\
\text { teachers }\end{array}$ \\
\hline $\begin{array}{l}\text { Arumugham } \\
\text { (2020). }\end{array}$ & $\begin{array}{l}\text { Asian People Journal (APJ); } \\
\text { Vol. 3, No. 1; } 2020\end{array}$ & $\begin{array}{l}\text { Curriculum, } \\
\text { Teaching and } \\
\text { Assessment from } \\
\text { The Perspective of } \\
\text { Classroom } \\
\text { Assessment } \\
\text { Implementation }\end{array}$ & $\begin{array}{l}\text { Ten teachers } \\
\text { directly } \\
\text { involved with } \\
\text { the } \\
\text { implementation } \\
\text { of CA years one } \\
\text { to three }\end{array}$ \\
\hline $\begin{array}{l}\text { Lee et } \\
(2020)\end{array}$ & $\begin{array}{l}\text { Journal of Dedicated } \\
\text { Research; Vol. 18, No. 2; } \\
2020\end{array}$ & $\begin{array}{l}\text { The Experience of } \\
\text { Instructional } \\
\text { Counsellors and } \\
\text { Teachers in the } \\
\text { Process of } \\
\text { Instructional } \\
\text { Guidance for } \\
\text { Classroom }\end{array}$ & $\begin{array}{l}\text { An instructional } \\
\text { guide and a } \\
\text { teacher }\end{array}$ \\
\hline
\end{tabular}




\begin{tabular}{|c|c|c|c|c|}
\hline & & & $\begin{array}{l}\text { Assessment in a } \\
\text { Primary School }\end{array}$ & \\
\hline $\begin{array}{l}\text { Lius } \\
\text { Mahamod } \\
(2021)\end{array}$ & $\&$ & $\begin{array}{l}\text { World Journal of Education; } \\
\text { Vol. 3, No. 1; } 2021 .\end{array}$ & $\begin{array}{l}\text { Stress Level } \\
\text { among Bahasa } \\
\text { Melayu Teachers } \\
\text { toward classroom } \\
\text { assessment } \\
\text { implementation in } \\
\text { Chinese National } \\
\text { Type School }\end{array}$ & $\begin{array}{l}128 \text { Malay } \\
\text { Language } \\
\text { teachers from } \\
13 \text { SJKC around } \\
\text { Johor }\end{array}$ \\
\hline $\begin{array}{l}\text { Salleh et } \\
\text { (2019) }\end{array}$ & al. & $\begin{array}{l}\text { International Seminar on } \\
\text { Educational Issues, } 2019\end{array}$ & $\begin{array}{l}\text { Teacher Literacy } \\
\text { Levels Towards } \\
\text { Approaches in } \\
\text { Classroom } \\
\text { Assessment }\end{array}$ & $\begin{array}{l}500 \text { teachers in } \\
\text { three districts in } \\
\text { the state of } \\
\text { Kedah }\end{array}$ \\
\hline $\begin{array}{l}\text { Khamis } \\
\text { Selamat. } \\
\text { (2019) }\end{array}$ & \& & $\begin{array}{l}\text { International Journal of } \\
\text { Academic Research in } \\
\text { Progressive Education and } \\
\text { Development; Vol. 8, No. 3; } \\
2019\end{array}$ & $\begin{array}{l}\text { The Use of } \\
\text { Feedback in the } \\
\text { Classroom } \\
\text { Assessment: A } \\
\text { Case Study }\end{array}$ & $\begin{array}{l}\text { Eight teachers } \\
\text { from primary } \\
\text { school - Cluster } \\
\text { School of } \\
\text { Excellence } \\
\text { teachers in } \\
\text { Malacca }\end{array}$ \\
\hline Omar. (2019 & & $\begin{array}{l}\text { Malay Language Education } \\
\text { Journal; Vol. 9; } 2019\end{array}$ & $\begin{array}{l}\text { Knowledge, Skills, } \\
\text { Attitude and } \\
\text { Problems in } \\
\text { Implementing the } \\
\text { Classroom } \\
\text { Assessment } \\
\text { among Malay } \\
\text { Language } \\
\text { Teachers in } \\
\text { Primary Schools }\end{array}$ & $\begin{array}{l}95 \text { Malay } \\
\text { teachers in rural } \\
\text { schools in } \\
\text { Betong district, } \\
\text { Sarawak }\end{array}$ \\
\hline $\begin{array}{l}\text { Jusoh } \\
\text { Mahamod. } \\
\text { (2019) }\end{array}$ & \& & $\begin{array}{l}\text { The International } \\
\text { Conference of Future } \\
\text { Education and Advances } \\
\text { (ICOFEA) } 2019\end{array}$ & $\begin{array}{l}\text { The level of } \\
\text { knowledge, } \\
\text { progress and } \\
\text { problems in } \\
\text { implementing } \\
\text { teacher } \\
\text { evaluation } \\
\text { formative } \\
\text { assessment in the } \\
\text { classroom Malay } \\
\text { Language Level } 1\end{array}$ & $\begin{array}{l}63 \quad \text { Malay } \\
\text { language } \\
\text { teachers' level } 1 \\
\text { in Betong }\end{array}$ \\
\hline Yeh (2021). & & $\begin{array}{l}\text { Journal of Art and Art } \\
\text { Education; Vol. 9, No. 1; } \\
2021\end{array}$ & $\begin{array}{l}\text { Challenges faced } \\
\text { by Visual Arts } \\
\text { Education with }\end{array}$ & $\begin{array}{l}\text { Nine } \quad \mathrm{VAE} \\
\text { teachers in } \\
\text { three national }\end{array}$ \\
\hline
\end{tabular}




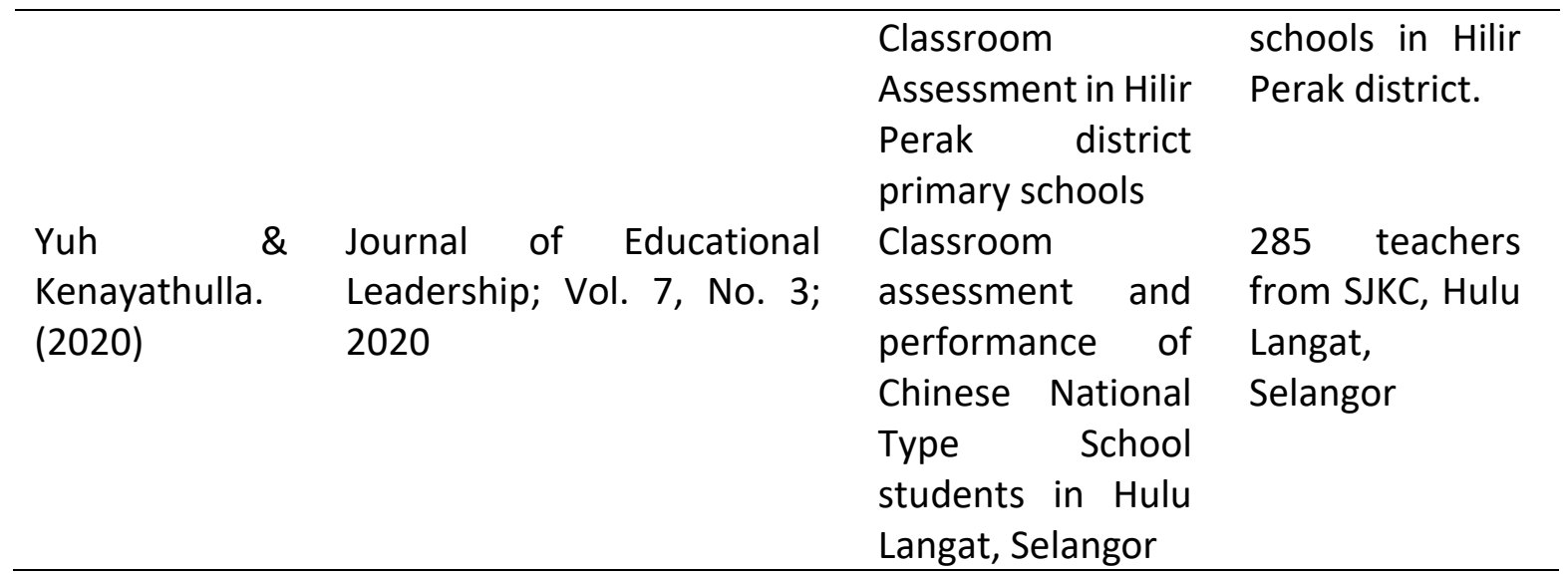

\section{Findings}

The study's findings will be discussed to answer the research questions. To answer the first research question, researchers identified five issues selected by previous researchers in conducting classroom assessment research in Malaysia, as shown in Table 2. According to table 2, the classroom assessment study conducted in Malaysia from 2020 to 2021 has various research issues. First, most previous researchers attempted to assess the level of teacher readiness for classroom assessment implementation (Dorin \& Yasin, 2019; Salleh et al., 2019; Omar, 2019; Jusoh \& Mahamod, 2019; Yeh, 2021). Furthermore, three types of research concentrate on teachers' methods or practices in implementing classroom assessment in Malaysia (Isa et al., 2020; Khory et al., 2021; Khamis \& Selamat, 2019). The need for guidance and monitoring was then identified in two additional studies to ensure the effectiveness of classroom assessment implementation in Malaysia (Arumugham, 2020; Lee et al., 2020). Following that, Lius and Mahamod (2021) conducted a study to determine the stress level experienced by teachers when implementing classroom assessments. Finally, Yuh and Kenayathulla (2020) investigated the relationship between classroom assessment implementation and student performance. All of the findings clearly show that, over the last two years, studies on classroom assessment implementation in Malaysia have focused on various aspects related to classroom assessment implementation to provide a holistic view to improve the effectiveness of classroom assessment implementation.

Table 2: Issues that have been studied

\begin{tabular}{|c|c|c|}
\hline Issues & Frequency (f) & Researchers \\
\hline Teacher's readiness & 5 & $\begin{array}{l}\text { Dorin \& Yasin (2019); } \\
\text { Salleh et al. (2019); Omar } \\
\text { (2019); Jusoh \& Mahamod } \\
\text { (2019); Yeh (2021) }\end{array}$ \\
\hline Practices & 3 & $\begin{array}{l}\text { Isa et al. (2020); Khory et al. } \\
\text { (2021); Khamis \& Selamat } \\
\text { (2019) }\end{array}$ \\
\hline Supervision and guidance & 2 & $\begin{array}{l}\text { Arumugham (2020); Lee et } \\
\text { al. (2020) }\end{array}$ \\
\hline Level of stress & 1 & Lius \& Mahamod (2021) \\
\hline Students' performance & 1 & Yuh \& Kenayathulla (2020) \\
\hline
\end{tabular}


DEVELOPMENT

Vol. 11, No. 1, 2022, E-ISSN: 2226-6348 @ 2022 HRMARS

To answer research question number two, five researchers use the qualitative approach. In the meantime, as shown in Table 3, seven other researchers used a quantitative approach. Researchers who used a qualitative approach gathered information by interviewing participants, analysing documents, and observing them. A questionnaire was used to collect data during quantitative research.

Table 3: Research methodology that has been used

\begin{tabular}{lll}
\hline \multicolumn{1}{c}{ Methodology } & Frequency (f) & \multicolumn{1}{c}{ Researchers } \\
\hline Qualitative & 5 & Arumugham. (2020); Lee et \\
& al. (2020); Khory et al. \\
& $(2021) ;$ Khamis \& Selamat \\
& $(2019) ;$ Yeh (2021) \\
Quantitative & Dorin \& Yasin (2019); Isa et \\
& al. (2020); Lius \& \\
& Mahamod (2021); Salleh et \\
& al. (2019); Omar (2019); \\
& Jusoh, \& Mahamod (2019); \\
& Yuh \& Kenayathulla (2020) \\
\hline
\end{tabular}

Finally, to answer research question number three regarding previous study findings, the main findings are presented in table 4 according to the issues studied. Only the study by Yeh (2021) found that teachers are not ready to implement classroom assessment, whereas Wan Omar (2019) discovered that teachers are ready to implement classroom assessment. Next, Dorin and Yasin (2019) discovered that teachers' readiness levels were medium to high. Finally, teachers with good knowledge and understanding of classroom assessment implementation were identified as the study's findings by (Salleh et al., 2019; Jusoh and Mahamod, 2019).

Concerning teacher practice, Isa et al (2020) discovered that teachers use examination as a classroom assessment component. It has been demonstrated that teachers are still unable to change their exam-oriented learning. According to the research of Khory et al. (2021), classroom assessment implementation must begin with a plan. According to Khamis and Selamat (2019), the most critical part, feedback, must be used optimally to ensure the effectiveness of student learning.

Concerning supervision and guidance, both researchers (Arumugham, 2020; Lee et al., 2020) discovered that teachers still require ongoing supervision and guidance to ensure classroom assessment implementation is successful. Furthermore, Lee et al. (2020) discovered that instructional coaches must improve their supervision approach to share other teaching strategies, teach modelling, and create relevant checklists for teaching strategies used in the classroom.

Finally, as a new policy, teachers in Lius and Mahamod's (2021) study identified stress in implementing classroom assessment, specifically in Malay Language subjects. However, because classroom assessment positively affects student performance, its implementation should be continuously improved (Yuh and Kenayathulla, 2020). 
Table 4: Main findings of previous studies

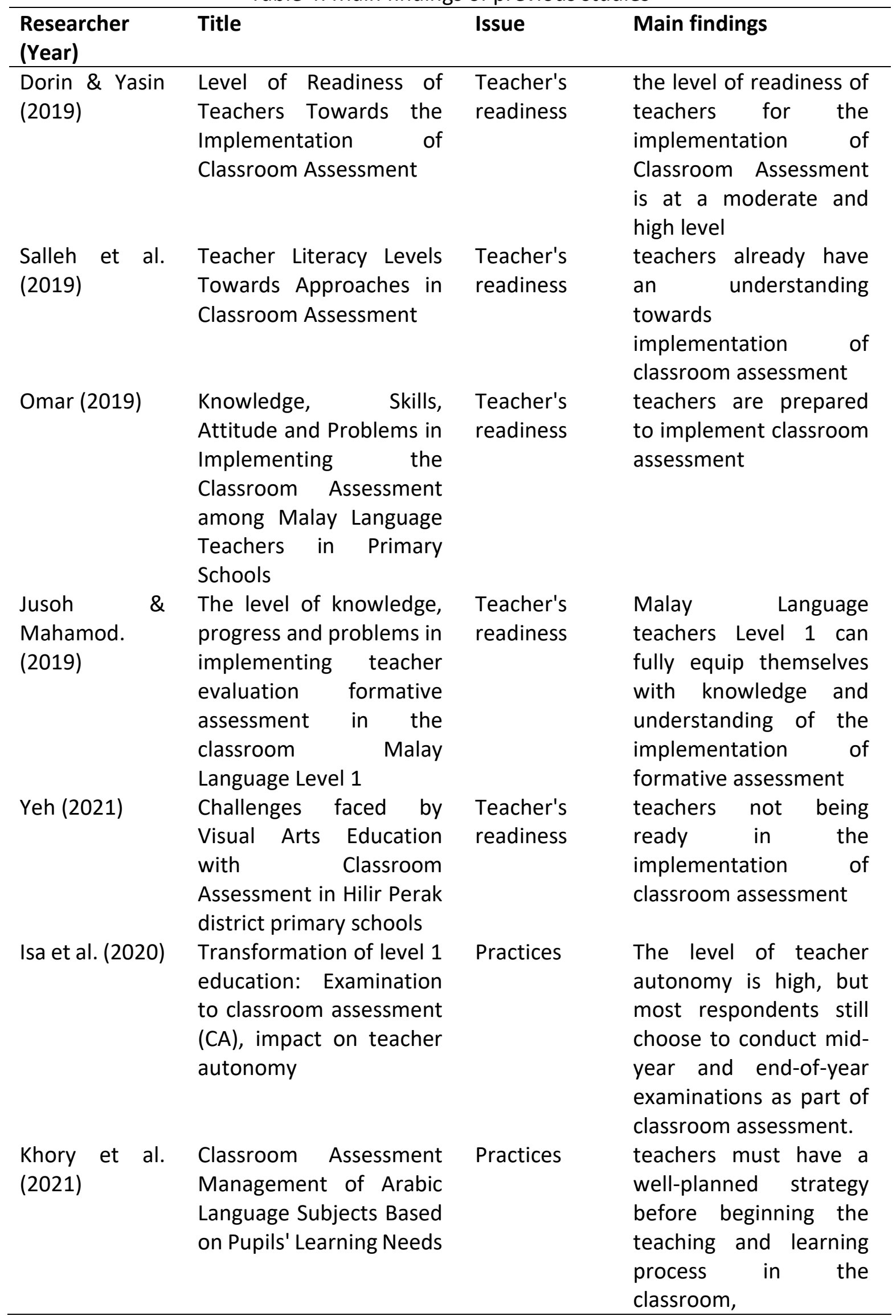




\section{DEVELOPMENT}

Vol. 11, No. 1, 2022, E-ISSN: 2226-6348 @ 2022 HRMARS

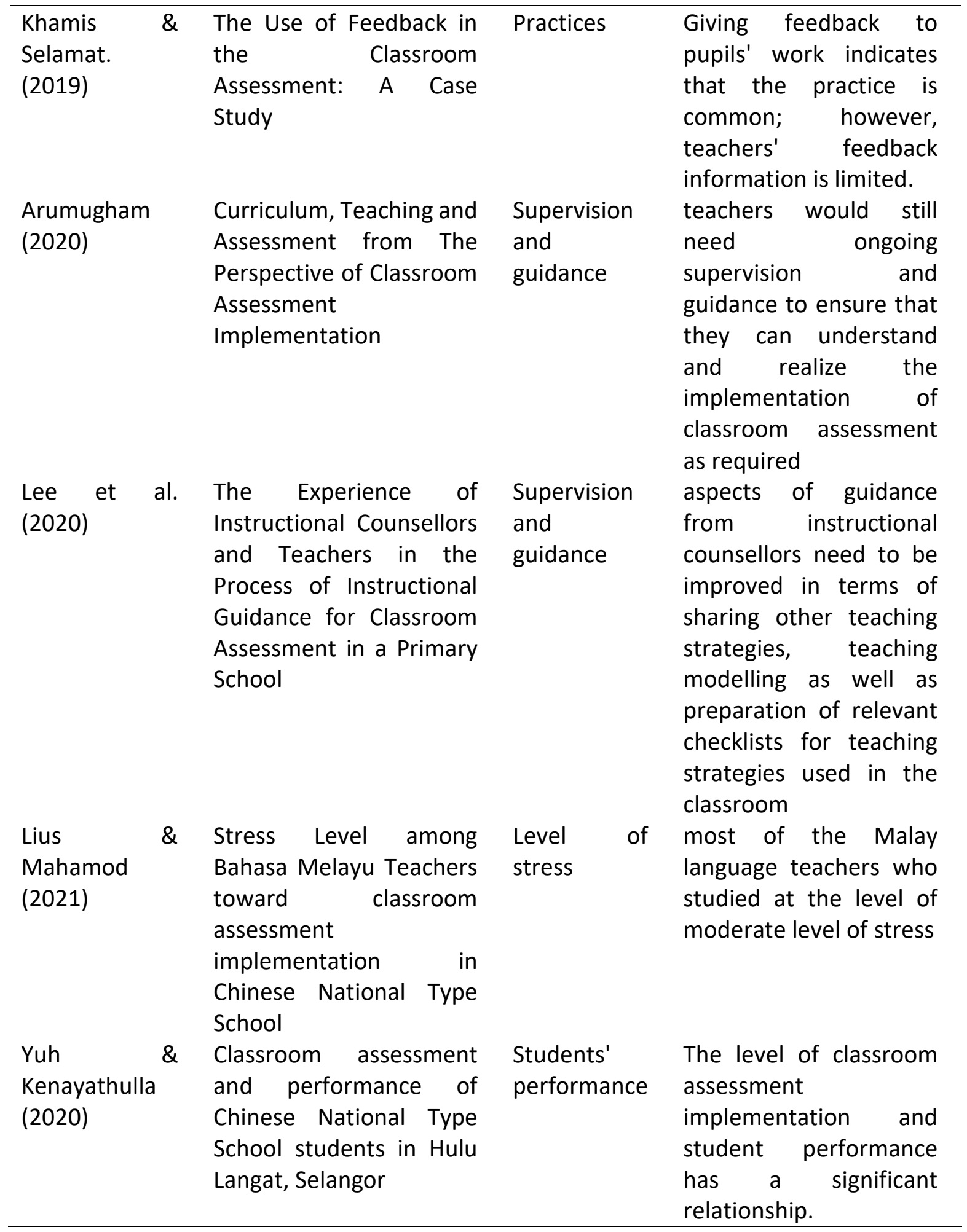

\section{Discussion}

Classroom assessment studies conducted in Malaysia from 2020 to 2021 had a range of purposes. Despite having different objectives, several studies looked at the same issues. Dorin and Yasin (2019); Salleh et al (2019); Yeh (2021); Jusoh and Mahamod (2019); Omar (2019), for example, sought to assess the extent of teacher readiness in implementing classroom assessment. Except for Yeh (2021), which found that teachers are not ready to implement 
classroom assessment, all studies found that teachers are ready. These differences explained why not all teachers are ready to implement classroom assessment, particularly teachers who taught subjects outside of their expertise. Teachers experienced stress as a result of their lack of readiness to execute classroom assessments, according to the findings of a study done by Lius and Mahamod (2021). Teachers were ineffective in providing effective feedback, even though feedback is an essential component in implementing classroom assessment (Khamis \& Selamat, 2019). According to a study conducted by Isa et al. (2020), teachers continue to implement classroom assessment through examination. As a result, it is adequate that researchers Arumugham (2020); Lee et al (2020) discovered that teachers still require regular guidance to ensure that classroom assessment is implemented according to the MOE's original concept. Teachers should also be aware that implementing classroom assessments will be more effective if they plan ahead of time before beginning the teaching and learning process (Khory et al., 2021). Teachers must pay close attention to planning because it allows them to identify students' learning needs, make classroom assessment more effective, and positively impact student performance (Yuh \& Kenayathulla. 2020). This finding demonstrates that studies on classroom assessment implementation in Malaysia conducted over two years have exhausted diverse aspects of classroom assessment to provide a holistic view for better practice.

The second feature is related to the methodologies used in the various studies on classroom assessment practises conducted in Malaysia. Five studies used a qualitative study design to conduct interviews, analyse documents, and observe real-world situations. The small sample size of respondents was a limitation. Furthermore, the lack of clarity on validation procedures hampered the study's interpretability and trustworthiness, leaving much desired. Seven other studies used a questionnaire as an instrument in a quantitative study design. Four of the seven studies (Dorin \& Yasin, 2019; Lius \& Mahamod, 2021; Isa et al., 2020; Salleh et al., 2019) did not state how well the instruments used met the criteria for validity and reliability. For example, Jusoh and Mahamod's (2019) study and Omar's (2019) study only explained instrument reliability by stating the Cronbach's alpha value. Only Yuh and Kenayathulla (2020) explained the instrument's validity and reliability. However, they only consider language validity and content validity. Previous researchers did not specifically mention instrument validity and reliability, possibly because the focus of their study did not specifically focus on instrument development and validation.

\section{Conclusion}

This meta-analysis study discovered that most researchers pay less attention to the validity and reliability of the instrument, particularly in quantitative studies. While validity and reliability are essential, each researcher must strictly adhere to ensure that the data collected is measured accurately using accurate measuring tools. As a result, future research should develop a valid instrument that meets the criteria for validity and reliability.

\section{References}

Arumugham, K. S. (2020). Kurikulum, pengajaran dan pentaksiran dari perspektif pelaksanaan pentaksiran bilik darjah. Asian People Journal (APJ), 3(1), 152-161.

Black, P., \& Wiliam, D. (2018). Classroom assessment and pedagogy. Assessment in Education: Principles, Policy and Practice, 25(6), 551-575. https://doi.org/10.1080/0969594X.2018.1441807 
Dorin, A. D., \& Yasin, R. M. (2019). Tahap kesediaan guru terhadap pelaksanaan pentaksiran bilik darjah (PBD). The International Conference of Future Education and Advances (ICOFEA) 2019, 8-15.

Ghazali, N. H. C. M, Rabi, N. M., Hassan, N. M., \& Wahab, N. A. (2018). A confirmatory factor analysis of classroom assessment practises scale in a Malaysian context. International Journal of Academic Research in Progressive Education and Development, 7(3), 516-529.

Isa, A. M., Mydin, A., Abdullah, A. G. K., \& Rasidi, M. W. F. (2020). Transformasi pendidikan tahap 1: Peperiksaan ke pentaksiran bilik darjah (PBD), kesan terhadap autonomi guru. In Habidin, N.F., Chik, T.W.T., Yong, S.Y.O., Muhammad, U.A., \& Fuzi, N.M., Isu dan cabaran dalam pendidikan: Strategi dan inovasi (pp. 218-231). Kaizentrenovation Sdn. Bhd.

Jusoh, W. N. A. S. W., \& Mahamod, Z. (2019). Tahap pengetahuan, pelaksanaan dan masalah guru dalam melaksanakan penilaian formatif dalam pentaksiran bilik darjah (PBD) Bahasa Melayu Tahap 1. The International Conference of Future Education and Advances (ICOFEA) 2019, 788-795.

Khamis, S., \& Selamat, A. (2019). The use of feedback in the classroom assessment: A case study. International Journal of Academic Research in Progressive Education and Development, 8(3), 325-334.

Khory, H. H. M., Rahman, M. N. A., \& Zailani, M. A. (2021). Pengurusan pentaksiran bilik darjah mata pelajaran bahasa arab berasaskan keperluan pembelajaran murid. Jurnal Kepimpinan Pendidikan, 8(2), 41-57.

Lee, T. A., Mahayudin, Z., Yuan, O. S., Mooi, O. Y., \& Teng, N. L. (2020). Pengalaman pembimbing instruksional dan guru dalam proses bimbingan instruksional pentaksiran bilik darjah di sebuah sekolah rendah. Jurnal Penyelidikan Dedikasi, 18(2), 60-73.

Lius, L., \& Mahamod, Z. (2021). Tahap tekanan guru bahasa melayu di sekolah jenis kebangsaan cina terhadap pelaksanaan pentaksiran bilik darjah. Jurnal Dunia Pendidikan, 3(1), 361-373.

McMillan, J. H. (2018). Classroom assessment: principles and practice that enhance student learning and motivation (7th ed.). Pearson Education, Inc. https://doi.org/August 3, 2017

Omar, S. S. H. W. (2019). Pengetahuan, kemahiran, sikap dan masalah guru dalam melaksanakan Pentaksiran Bilik Darjah Bahasa Melayu di sekolah rendah. Jurnal Pendidikan Bahasa Melayu, 9(3), 56-67.

Pilok, S., Ahmad, A. R., \& Awang, M. M. (2019). The readiness of history teachers in implementing classroom assessment. Global Conferences Series: Social Sciences, Education and Humanities (GCSSSEH), 2, 192-196.

Rahman, M. M. (2018). Exploring science teachers' perception of classroom assessment in secondary schools of Bangladesh. European Journal of Education Studies, 4(9), 139-160.

Salleh, M., Sarkowi, A., Jafar, M. F., Arif, Z. M., \& Hamid, H. A. (2019). Tahap literasi guru terhadap pendekatan dalam pentaksiran bilik darjah. Seminar Antarabangsa Isu-Isu Pendidikan (ISPEN 2019), 12-24.

Shepard, L. A. (2019). Classroom assessment to support teaching and learning. Annals of the American Academy of Political and Social Science, 683(1), 183-200.

Yeh, L. H. (2021). Cabaran yang dihadapi pendidikan seni visual dengan pentaksiran bilik darjah di sekolah rendah daerah Hilir Perak. Jurnal Seni Dan Pendidikan Seni, 9(1), 4657. 
INTERNATIONAL JOURNAL OF ACADEMIC RESEARCH IN PROGRESSIVE EDUCATION AND DEVELOPMENT

Vol. 11, No. 1, 2022, E-ISSN: 2226-6348 @ 2022 HRMARS

Yuh, T. J., \& Kenayathulla, H. B. (2020). Pentaksiran bilik darjah dan prestasi murid Sekolah Jenis Kebangsaan Cina di Hulu Langat, Selangor. JuPiDi: Jurnal Kepimpinan Pendidikan, 7(3), 70-90. 